Proceedings

\title{
Impact of Flora Communities on Nutrients Dynamics in Hyporheic Zone of Urban Spring Ecosystem ${ }^{+}$
}

\author{
Katarzyna Puczko * and Elżbieta Jekatierynczuk-Rudczyk
}

Department of Environmental Protection, Faculty of Biology, University of Bialystok, Ciołkowskiego 1J,

15-245 Białystok, Poland; rudczyk@uwb.edu.pl

* Correspondence: k.puczko@uwb.edu.pl

+ Presented at the 1st International Electronic Conference on Biological Diversity, Ecology, and Evolution, 1531 March 2021.

Citation: Puczko, K.;

Jekatierynczuk-Rudczy, E. Impact of

Flora Communities on Nutrients

Dynamics in Hyporheic Zone of

Urban Spring Ecosystem. 2021, 68, x. https://doi.org/10.3390/xxxxx

Published: date

Publisher's Note: MDPI stays neutral with regard to jurisdictional claims in published maps and institutional affiliations.

\section{Copyright: (c) 2021 by the authors.}

Submitted for possible open access

publication under the terms and

conditions of the Creative Commons

Attribution (CC BY) license

(http://creativecommons.org/li-

censes/by/4.0/).

\begin{abstract}
Hyporheic zone (HZ) is an interstitial part of groundwater that can provide a spectrum of subsurface habitats depending on the spatial distribution of upwelling groundwater. Differentiation of environmental factors affects the abundance and distribution of plants associated with outflows of groundwater. Plant communities in spring niches dependence on permanent, relatively cold water that not freeze in winter. High dynamics of redox conditions and low temperature increase the intensity of nitrification, denitrification and ammonification processes. We hypothesized that groundwater upwelling enrich surface water with biogenic compounds, and it depends on among others the flora communities. Research were conducted in two lowland spring niches in suburbs of Białystok. Interstitial samples were collected with mini-piezometers. The analysis of flora included: vascular plants and bryophytes. Nutrient analysis were conducted using chromatographic methods, organic carbon analyser and Kjeldahl analyser. The springs studied differed in their richness of species, which is associated with varying degree of human impact and the environmental factors (water quality, geological, morphological, hydrological). Hydrophilic vegetation performs a stabilizing function by assimilating nitrogen compounds and contributing to a variations in nutrients concentration. Many species of water bryophytes, due to their high sensitivity to water quality, are considered a bioindicator of oligotrophy and mesotrophy. The richness of vascular plants in niches in the suburbs was smaller compared to the flora of lowland springs located in natural areas, but the presence of species under protection indicates a high degree of naturalness of the environment. Plant community richness can be a good indicator of the ecological status of lowland springs.
\end{abstract}

\section{Introduction}

Hyporheic zone (HZ) is an interstitial part of groundwater, the lower limit of which reaches depth, where the physical and chemical characteristics of water are stable in space and time (Brunkeand Gonser, 1997). HZ is a transition zone between groundwater and surface waters that can provide a spectrum of subsurface habitats depending on the spatial distribution of upwelling groundwater and downwelling surface water. It is an important place of metabolic processes of river water that consider physical processes (hydraulic retention, surface and groundwater mixing, thermal fluctuations), biological processes (primary production, microbiological decomposition, uptake by plants, release by macrozoobenthos) and chemical processes (for example: carbon and nutrient cycling).

Differentiation of environmental factors affects the abundance and distribution of plants associated with groundwater outflow. Plant communities in spring niches dependence on permanent, relatively cold water that not freeze in winter. High dynamics of redox conditions and low temperature increase the intensity of nitrification, denitrification and ammonification processes (Jekatierynczuk-Rudczyk 2007). We hypothesized that groundwater upwelling enrich surface water with biogenic compounds, and it depends on among others the flora communities. 


\section{Material and Methods}

The research was conducted in suburbs of Bialystok (Figure 1). Białystok lies in the Podlasie province, in the north-eastern part of Poland. The city is situated in the Białystok Upland of the Podlaskie Plain. The region is characterised by high natural values, and is part of what is known as the Green Lungs of Poland. Near the city, there are many unique natural ensembles on a European scale include the Narew National Park (a swampy valley with moraine hills typical of a braided river) and the Knyszyn Forest Landscape Park (one of the best preserved forest complexes in Poland). Due to the occurrence of unique environmental values, Białystok was the first city in Poland in 1993 to be admitted to the Healthy Cities Network of the World Health Organisation.
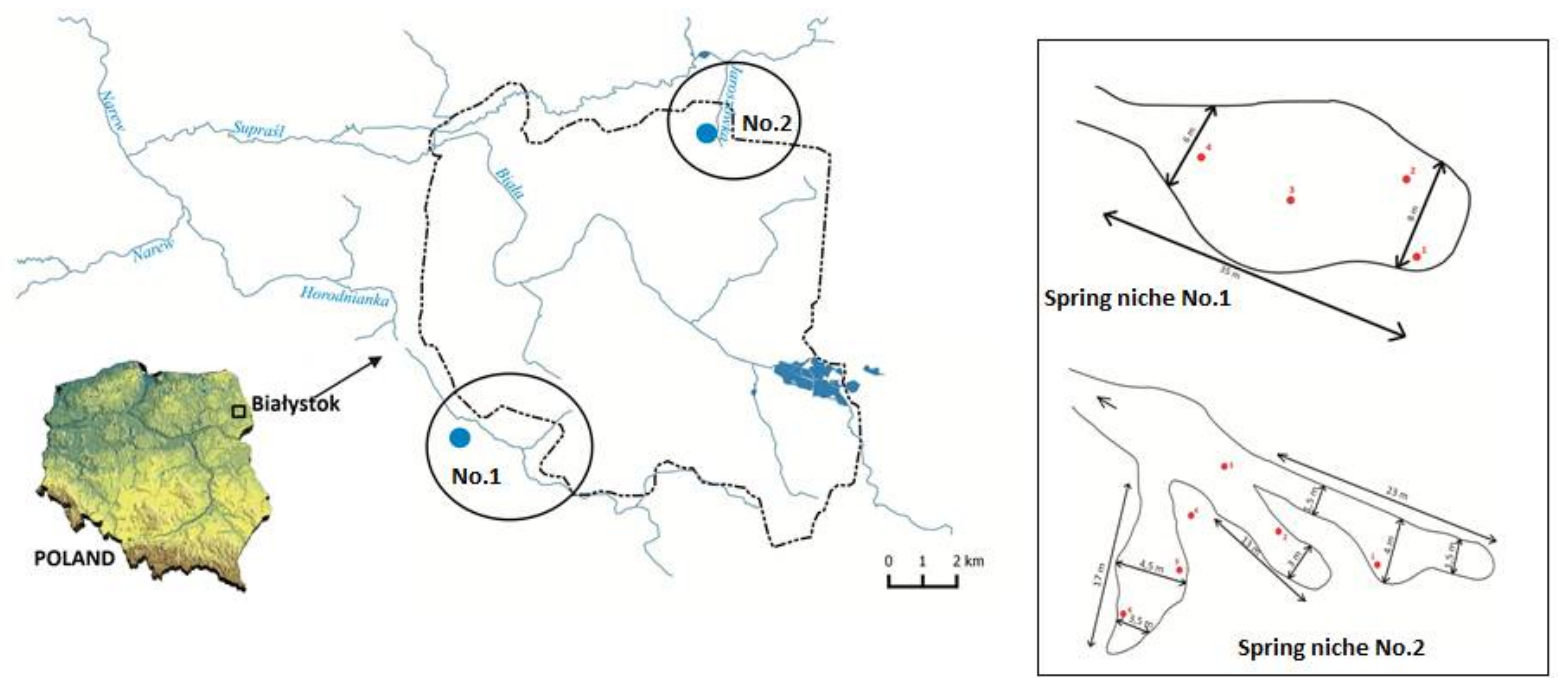

Figure 1. Hydrographic map of spring niches in Białystok with the location schemes of piezometers in spring niches No.1(Horodnianka catchment) and No.2 (Jaroszówka catchment).

In hydrological terms, the study area belongs to the Vistula river catchment and the Baltic Sea basin. Bialystok city is situated within the fourth-order catchment, including the Biała and Jaroszówka rivers (Figure 1). The area of the city is mostly deforested, and hydrological conditions are significantly changed. Despite the transformations of surface and groundwater, the Białystok region still has a well-preserved natural environment, which is confirmed by the presence of spring niches. During crenological mapping, 11 spring niches were inventoried and described in Bialystok and suburbs. Complex hydrographic network owes its shape to varied terrain formed during the Weichselian glaciation.The area is characterized by the presence of moraine plateaus, the slopes of which are cut by numerous valleys. Two natural groundwater outflows with different geomorphological locations and niche formations were selected for field tests. Spring No1 located in south-west part of city and spring No.2 located in north-east part of Bialystok.

The research was conducted in 2019 before, during and after the end of the growing season in monthly cycles. Patches of vegetation in the spring niche were characterized. All plants were determined to the species level, and the quantity and sociability of individual plant species were determined using the Braun-Blanquet scale (Braun-Blanquet 1932). The type of outflow, construction of the aeration zone and spring niche measurements were described. Surface water was taken from a concentrated outflow within the spring niche and from the middle section of the river. Interstitial samples were collected with minipiezometer. This allowed water collection from a depth of $30 \mathrm{~cm}$. Four piezometers were placed in spring niche No. 1, and six piezometers in spring niche No. 2.

Basic physical and chemical water parameters: electrolytic conductivity (EC), temperature, oxygen saturation and redox potential (Eh), were measured in the field by means of a HQ40 $\mathrm{m}$ by Hach Lange probe. Total hardness, magnesium $\left(\mathrm{Mg}^{2+}\right)$, calcium $\left(\mathrm{Ca}^{2+}\right)$, 
sodium $\left(\mathrm{Na}^{+}\right)$, potassium $\left(\mathrm{K}^{+}\right)$, chlorides $\left(\mathrm{Cl}^{-}\right)$, sulfates $\left(\mathrm{SO}_{4}{ }^{2-}\right)$, ammonium nitrogen $\left(\mathrm{NH}_{4}{ }^{+}-\right.$ $\mathrm{N})$ and nitrate nitrogen $\left(\mathrm{NO}_{3}{ }^{-} \mathrm{N}\right)$ were analysed using the HPLC method. Bicarbonates $\left(\mathrm{HCO}_{3}^{-}\right)$were determined by titration with hydrochloric acid $(\mathrm{HCl})$ in the presence of an indicator-methyl orange (APHA 1998). Analyses of total organic carbon (TOC) and dissolved organic carbon (DOC) concentrations were carried out using the Shimadzu carbon analyser. Particulate organic carbon (POC) was calculated as the difference between TOC and DOC concentrations. Total organic nitrogen (TON) was analysed by Tecator 2300 (Kjeldahl analyser). Phosphorus ions were determined by the molybdenum method. Concentrations of the total iron (TFe) were analysed by applying the spectrophotometric method with 1,10-phenantroline.

\section{Results and Discussion}

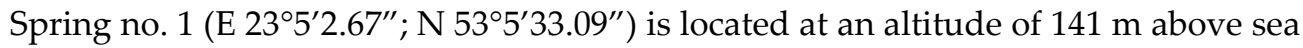
level in the Turczyński Forest in the Horodnianka catchment. It is an outflow with a shallowly indented niche with an area of about $250 \mathrm{~m}^{2}$ and a depth of $0.5 \mathrm{~m}$. The aeration zone consists of sands and gravels. Mineral deposits in the discharge niche are covered with a thin layer of organic matter. The niche is surrounded by a mixed fresh forest composed of Pinus sylvestris, Carpinus betulus, Quercus robur. Bush layer is dominated by Corylus avellana.

Spring no. 2 (E $23^{\circ} 11^{\prime} 57.87^{\prime \prime} ; \mathrm{N} 53^{\circ} 10^{\prime} 32.2^{\prime \prime}$ ) is located in the Jaroszówka river catchment at an altitude of $140 \mathrm{~m}$ above sea level. It is an outflow with a deeply indented threepart niche with slopes up to $3 \mathrm{~m}$. The aeration zone is made of various-grained sands, and the surrounding niche is a mixed forest. Due to the shading, the bottom of the niche is almost completely devoid of vegetation. The spring niche was a landfill site for many years. Now the garbage is lying under a thin layer of soil. The waste has been immobilized and overgrown with vegetation, and a thick layer of forest litter has effectively hidden huge trash heaps.

Springs in the suburban area of Białystok were characterized by a thaw regime and low water circulation with yield fluctuations typical of north-eastern Poland. Springs were characterized by yield not higher than $1.7 \mathrm{~L} / \mathrm{s}$. Measurements of piezometers filling time allowed determining the water circulation rate in various parts of the spring niche. In different parts of the niche, the water circulation rate was variable. Spring niche No. 1 was characterized by greater average variability of water yield $(\mathrm{Cv}=47 \%)$ compered to spring niche No. $2(\mathrm{Cv}=40 \%)$. Short-term summer rainfalls do not result in an increase in spring water yield. This is due to low infiltration and increased evaporation in the summer. Increased water yield can be the result of infiltration during intense and continuous rainfall (Jekatierynczuk-Rudczyk 1999). The highest water pressure was recorded in the central part of the niche of spring No. 1 in P2. Maximum yield of $1.7 \mathrm{dm}^{3} \mathrm{~s}^{-1}$ was observed in spring No.1 in September. The lowest water yield was observed in May.

River, spring and interstitial waters were characterized by different values of physical and chemical parameters (Table 1). The water temperature in interstitial waters was 2 degrees lower than the surface water temperature. Oxygenation of the water increased significantly along the course of the river. In piezometers, water was $39 \%$ (spring No. 1) and $26 \%$ (spring No. 2) saturated with oxygen. During the flow, the water oxygenated and saturation values increased to around $90 \%$. In the Jaroszówka catchment, the $\mathrm{pH}$ value was slightly higher than in the Horodnianka catchment. In the Jaroszówka catchment waters were characterized by twice higher concentrations of magnesium, sulfate and sodium ions and eight times higher concentrations of potassium ions compare to Horodnianka catchment. This clearly indicates a very large transformation of water quality and its pollution as a result of leaching from the landfill.

Table 1. Water quality characteristic (mean value \pm standard deviation) of interstitial waters, streams and rivers studied (post hoc Tukey HSD test $(p<0.05)$ ). 


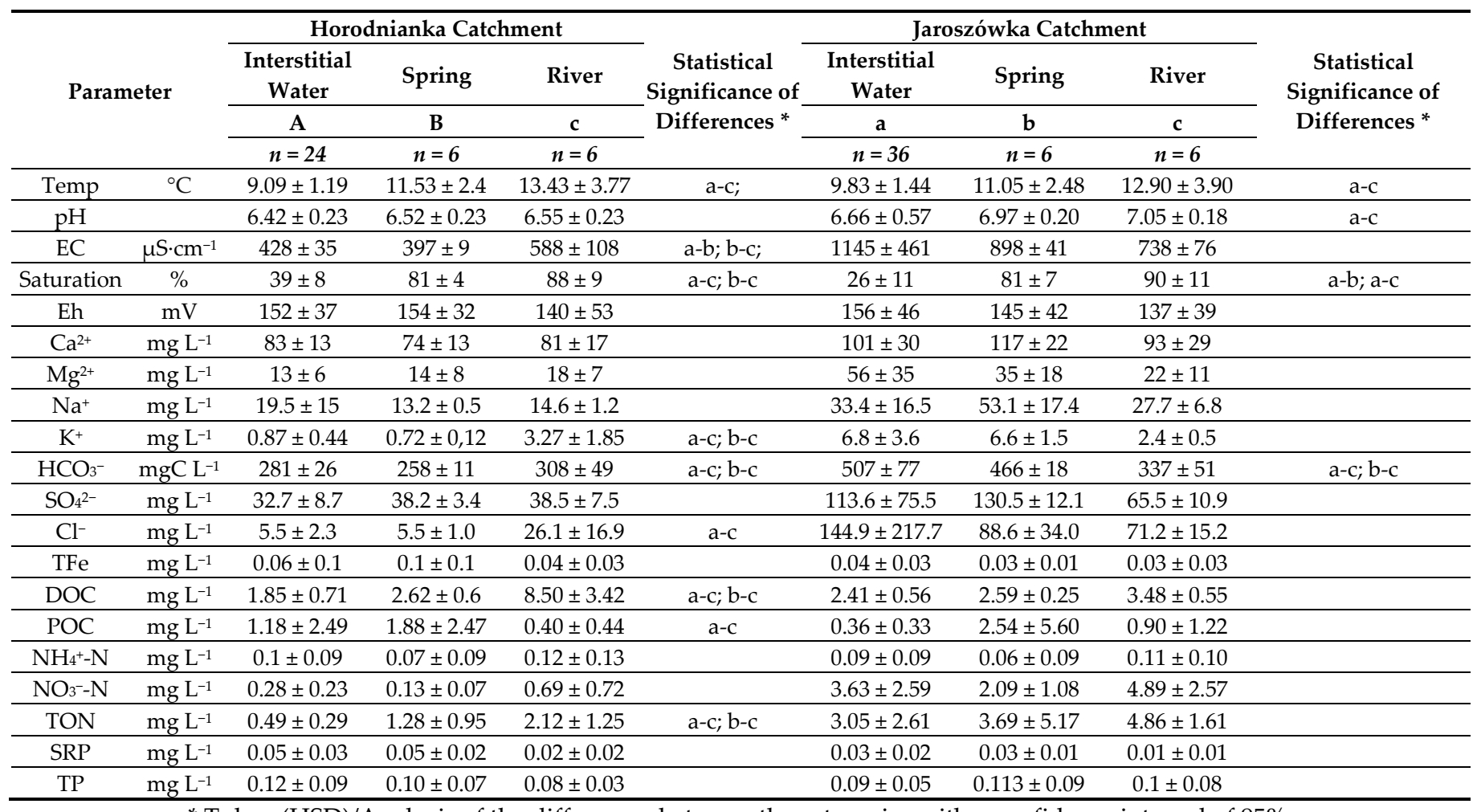

* Tukey (HSD)/Analysis of the differences between the categories with a confidence interval of $95 \%$.

Dissolved organic carbon concentration increased from the spring water to the river water. There were twice less nitrate ions in the surface water than in interstitial water, which indicates the assimilation of nitrate ions by plants growing on the bottom of the spring niche No.1. In groundwater and surface water, average TP and SRP concentrations were similar throughout the year. Phosphorus ions are taken up by plants in the growing season. The concentration of phosphorus did not increase in surface waters, so there is a little inflow from catchment.

Surface water is enriched with allochthonous and autochthonous DOC from a catchment along the river course. In interstitial waters there are many processes like the formation of complex compounds on the surface of minerals, adsorbing processes in suspension or incorporation into biomass by organisms inhabiting the HZ (Stegen et al. 2018, Puczko, Jekatierynczuk-Rudczyk 2020). In spring No.2 concentration of DOC was higher in interstitial waters compare to surface waters what can be associated with percolation of organic compounds from landfill. The full vegetation season on July resulted in a slight decomposition of organic matter and resulted high concentration of POC. A high variety in the concentration of nitrogen compounds was observed in all types of water examined. High dynamics of redox conditions increase the intensity of such processes as nitrification, denitrification and ammonification, affecting the variable gradient of nitrogen compounds concentration in interstitial. The highest concentration of ammonium ions, nitrates $(\mathrm{V})$ and organic nitrogen was recorded in rivers, which results from the catchment inflow. In interstitial waters of both springs, high concentration of ammonium and nitrate ions was recorded compared to their content in the outflow. In spring No. 1, there were two times less nitrate ions in the surface water than in interstitial water. Organic nitrogen predominated in the structure of nitrogen compounds in all studied types of water.

In total, 19 species of vascular plants were recorded (Table 2). The species present in both spring niches are marked in blue. Spring niche No. 1 was characterized by a greater species richness of plants. At the peak of the growing season, at the turn of June and July, vegetation grew $75 \%$ of the niche bottom surface. The dominant species were Veronica beccabunga and Nasturtium officinale. Large clusters of Lemna minor and Lemna trisulca were 
also observed. The richness of vascular plants in niches in the suburbs was smaller compared to the flora of lowland springs located in natural areas (Puczko et al. 2018). However, in both niches there were observed Nasturtium officinale, that is protected species in Poland. The typical habitat of Nasturtium officinale are slow flowing shallow waters, periodically flooded areas and springs.

Table 2. Species of vascular plants found in spring niches with relative abundance and sociability.

\begin{tabular}{|c|c|c|c|c|}
\hline \multirow{2}{*}{ Vascular Plant } & \multicolumn{2}{|c|}{ Spring Niche NO.1 } & \multicolumn{2}{|c|}{ Spring Niche NO.2 } \\
\hline & Abundance & Sociability & Abundance & Sociability \\
\hline Athyrium filix-femina L. Roth & + & 2 & & \\
\hline Cirsium oleraceum L. Scop. & & & + & 2 \\
\hline Epilobium palustre L. & + & 1 & & \\
\hline Equisetum fluviatile L. em. Ehrh. & + & 1 & + & 1 \\
\hline Equisetum palustre L. & & & + & 1 \\
\hline Galium palustre L. & + & 2 & & \\
\hline Lemna minor L. & 2 & 4 & & \\
\hline Lemna trisulca L. & 2 & 4 & & \\
\hline Lysimachia vulgaris L. & + & 1 & & \\
\hline Mentha aquatica L. & 1 & 2 & & \\
\hline Myosotis scorpioides L. & + & 1 & & \\
\hline Nasturtium officinale W. T. Aiton & 2 & 2 & 1 & 3 \\
\hline Oxalis acetosella L. & 1 & 2 & 1 & 1 \\
\hline Persicaria amphibia L. Delarbre & + & 1 & & \\
\hline Poa palustris $\mathrm{L}$. & + & 1 & & \\
\hline Ranunculus repens L. & + & 1 & + & 1 \\
\hline Stellaria holostea L. & & & + & 1 \\
\hline \multirow[t]{2}{*}{ Veronica beccabunga L. } & 2 & 2 & \multirow{2}{*}{\multicolumn{2}{|c|}{ in total: 8 species }} \\
\hline & in total: 1 & species & & \\
\hline
\end{tabular}

In total, 5 species of mosses and 1 species of liverwort were recorded (Table 3). The species present in both spring niches is marked in blue. The bryophytes formed irregular clusters with a compact composition mainly of three species: Brachytecium rivulare, Plagiomnium undulatum and Rhizomnium punctatum. Liverwort Pellia neesiana can usually be found growing on damp mineral (inorganic) soil in shaded and wet sites, along steambanks, lake-shores and swampy areas. Many species of water bryophytes, due to their high sensitivity to changes in the aquatic environment, including water quality, are considered indicator species, e.g., Brachytecium rivulare is considered a bioindicator of oligotrophy and mesotrophy. Leptodictyum riparium occurs in aquatic ecosystems with a significant degree of anthropogenic transformation. Generally, all identified bryophytes are common in river valleys and spring areas of central and eastern Poland.

Table 3. Species of bryophytes found in spring niches with relative abundance and sociability.

\begin{tabular}{ccccc}
\hline Bryophyte & Spring Niche NO.1 & \multicolumn{2}{c}{ Spring Niche NO.2 } \\
\cline { 2 - 5 } & Abundance & Sociability & Abundance & Sociability \\
\hline Brachythecium rivulare & 1 & 2 & & \\
$\begin{array}{c}\text { Schimp. } \\
\text { Plagiomnium undulatum } \\
\text { Hedw. T.J. Kop. }\end{array}$ & 1 & 1 & + & 1 \\
$\begin{array}{c}\text { Rhizomnium punctatum } \\
\text { Hedw. T.J. Kop }\end{array}$ & 1 & 1 &
\end{tabular}




Hypnum cupressiforme
Hedw.
Leptodictyum riparium
Hedw. Warnst.
Pellia neesiana Gottsche
Limpr.

in total: 5 species
1

\section{Summary}

Spring niches studied differed in their richness of organisms, which is associated with varying degrees of human transformation and water quality. Spring niche located in the Horodnianka catchment was characterized by a high degree of naturalness and good ecological status. Hydrophilic vegetation performs a buffer and stabilizing function by assimilation nitrogen compounds from water and contributes to a variety in nutrients concentration. Small temperature fluctuations in combination with high dynamics of redox conditions in interstitial waters affect the variable gradient of nitrogen compounds concentration in interstitial waters in space and time. Groundwater upwelling enrich surface water with biogenic compounds, especially DOC and TON. Hyporheic processes are complex, as evidenced by the mosaic distribution of the amount of organic matter along spring niches and small rivers. Based on the conducted research, it should be stated that biogeochemical processes occurring in the hyporheic zone of lowland springs in urban areas impact on the quality in the initial sections of urban rivers. However, this impact is various and limited in space.

Institutional Review Board Statement: Not applicable

Informed Consent Statement: Not applicable

Data Availability Statement: Not applicable

\section{References}

1. APHA. Standard Methods for the Examination of Water and Wastewater, 19th ed.; American Public Health Association: Washington, DC, USA, 1998.

2. Braun-Blanquet, J. Plant Sociology. The Study of Plant Communities, 1st ed.; McGraw-Hill Book Co., Inc.: New York, NY, USA; London, UK, 1932.

3. Brunke, M.; Gonser, T.O.M. The ecological significance of exchange processes between rivers and groundwater. Freshw. Biol. 1997, 37, 1-33.

4. Czarnecka, B. Springs of the Roztocze escarpment zone: The diversity of plant cover vs. environment quality. Infrastruct. Ecol. Rural Areas 2009, 6, 27-43.

5. Jekatierynczuk-Rudczyk, E. Effects of drainage basin management on the chemical composition of waters in lowland springs. Acta Hydrobiol. 1999, 41.

6. Jekatierynczuk-Rudczyk, E. Hyporheic zone, its functioning and meaning. Kosmos 2007, 1, 181-196.

7. Mazurek, M. Spring niches areas with a link between the cone system and the trough system, the Parsęta river basin. Landf. Anal. 2008, 9, 63-67.

8. Mirek, Z.; Piekoś-Mirkowa, H.; Zając, A.; Zając, M. Flowering Plants and Pteridophytes of Poland. A Checklist; W. Szafer Institute of Botany, PAN: Kraków, Poland, 2002.

9. Ochyra, R.; Żarnowiec, J.; Bednarek-Ochyra, H. Biodiversity of Poland. In Genus Catalogue of Polish Mosses; Academy of Sciences, Institute of Botany: Kraków, Poland, 2003; Volume 3.

10. Puczko, K.; Zieliński, P.; Jusik, S.; Kołakowska, A.; Jekatierynczuk-Rudczyk, E. Vascular plant and bryophyte species richness in response to water quality in lowland spring niches with different anthropogenic impacts. Environ. Monit. Assess. 2018, 190, $1-16$.

11. Puczko, K.; Jekatierynczuk-Rudczyk, E. Analysis of urban land cover influence to organic carbon and nutrients in surface water via impacted groundwater. Environ. Monit Assess 2020, 192, 145.

12. Szoszkiewicz, K.; Zbierska, J.; Jusik, S.; Zgoła, T. Macrophyte Method for River Assessment-Manual for the Assessment and Classification of Ecological Status of Running Waters Based on the Aquatic Plants; Bogucki Wydawnictwo Naukowe: Poznan, Poland, 2010.

13. Szweykowski, J. Biodiversity of Poland. An Annotated Checklist of Polish Liverworts and Hornworts; Academy of Sciences, Institute of Botany: Kraków, Polish, Poland, 2006; Volume 4. 